\title{
Harvesting, Storing, and Feeding Forages as Round Bale Silage 1
}

William E. Kunkle ${ }^{2}$

\section{Introduction}

Perennial warm-season grasses grown in Florida are often dried and harvested as hay. Florida weather data shows less than a $20 \%$ probability of 3 consecutive drying days from mid-June through August. These frequent rains often delay harvest and/or cause considerable field losses of forages. Maintaining a regular harvest schedule (every 4 to 5 weeks) during the summer months is essential for good forage quality.

Forages are often harvested at high moisture and ensiled when field drying is not feasible or possible. High costs for equipment and structures needed to chop, haul, and store silage has limited its use for perennial warm season forages especially for the medium and small beef and dairy producers. Forages have additional challenges because yields at each harvest are lower than corn or sorghums, they are cut several times during the summer, and they need to be wilted prior to ensiling which is not compatible with storing in bunker silos or in piles.
Development of systems for ensiling chopped forage in long polyethylene tubes was very applicable to timely harvest of warm season perennial forages in Florida. However, this system required costly specialized equipment for chopping and bagging the forage that limited its application to small medium beef and dairy producers. Round bale silage was developed in Europe and has been used since the mid-1980's in the U.S. Round bale silage is harvested with the same equipment used for making hay, requiring only the addition of a plastic wrapper for applying the "stretch wrap" to the bales. Round bale silage offers flexibility in harvesting small quantities at one time, requires less additional equipment purchase than chopped silage systems, offers flexibility of making hay when weather permits and silage when the weather necessitates, and does not require much additional equipment operation and repair skills. This paper will review the research, experiences, and challenges of the round bale harvesting, storing, and feeding system.

1. This document is AN145, one of a series of the Department of Animal Sciences, Florida Cooperative Extension Service, UF/IFAS. Published October 2003. Please visit the EDIS Web Site at http://edis.ifas.ufl.edu.

2. William E. Kunkle, former Professor and Extension Beef Specialist in the Department of Animal Sciences, Florida Cooperative Extension Service, UF/IFAS, Gainesville, FL 32611.

The use of trade names in this publication is solely for the purpose of providing specific information. UF/IFAS does not guarantee or warranty the products named, and references to them in this publication does not signify our approval to the exclusion of other products of suitable composition.

The Institute of Food and Agricultural Sciences (IFAS) is an Equal Employment Opportunity - Affirmative Action Employer authorized to provide research, educational information and other services only to individuals and institutions that function without regard to race, creed, color, religion, age, disability, sex, sexual orientation, marital status, national origin, political opinions or affiliations. For information on obtaining other extension publications, contact your county Cooperative Extension Service office. Florida Cooperative Extension Service / Institute of Food and Agricultural Sciences / University of Florida / Larry R. Arrington, Interim Dean 


\section{Forage Quality Declines with Maturity}

Bermuda and star grasses produce large yields during the warm season but quality declines rapidly after 4 weeks of regrowth (Table 1). These grasses are not high in quality at four weeks regrowth and allowing them to grow past six weeks does not increase yearly dry matter production and forage quality is near maintenance (QI - 1.0) or below. Growing or lactating cattle fed these forages will require more supplement to attain desired performance. Digit and limpo grasses are higher in quality than bermuda and star grasses at similar maturity but they also decline in quality during regrowth as the proportion of stem increases.

Research from Louisiana further emphasizes the importance of regrowth interval on forage quality (Table 2). The decline in quality reflected in gains of steers is more rapid in bermudagrass grown during the summer than in bermudagrass grown during the spring. Summer regrowth may have lower quality because higher temperatures increase lignin deposition and high rainfall increases growth rates and maturation. This further emphasizes the need to cut warm season perennial grasses every 4 weeks to retain quality.

Round bale silage allows you to harvest forage every 4 to 5 weeks when the quality is better. This reduces or eliminates the need for supplements when feeding the forage to livestock. We suggest developing a plan to cut warm season grasses by the calendar; make hay when the weather allows and make round bale silage when the weather will not allow you to make hay.

\section{Wrapping, Storing, and Feeding}

\section{Allowing air into ensiled forage will reduce the} quality of round bale silage. Preservation of wet forages requires that air (oxygen) be kept out. Molds and other organisms that rot wet forages need air to grow. If air enters, the forage molds initially, then rots over time. This has been the biggest problem for producers using the round bale system.

Round bale silage was first stored in individual bale bags that were put on bales lifted off the ground then gathered and tied with string to seal (Cromwell et al., 1994a). The bag cost ( $\$ 6$ to $\$ 8 / \mathrm{bag}$ ) and labor to put bales in bags limited adoption of this approach. Another approach tried was to store bales in long plastic tubes (a long bag) and mechanized bale tube stuffers were developed. The long tube was more cost effective ( $\$ 4$ to $\$ 5 / \mathrm{bale}$ ) and is still used by some producers. Our experience was that small hole(s) in one end allowed air to move freely in the tube resulting in molding of bales in too many instances. A more recent version of this system has tubes that are stretched in diameter while loading bales, which reduces air space and movement.

The "stretch wrap" round bale silage system has been used for over 10 years and has become the most widely used round bale silage storage system in Florida and across the U.S. The following discussions will address experiences with the stretch wrap storage system.

Stretch wrap plastic quality. Several producers have purchased stretch wrap plastic that was not stable in sunlight. The intense sunlight for many months in Florida can cause the plastic to lose its pliability and break up in pieces. Conditions in Florida require more additives in stretch wrap plastic to resist sunlight degradation compared to other areas of the U.S. In the early 1990's, four tests (each a year long) were conducted to evaluate stability of plastic in sunlight (Cromwell et al., 1997b). Some samples of plastic were stable in sunlight for less than a month, while others were stable for over a year. Sunlight stability was a noted problem when we started the tests but problems decreased over the years. After numerous contacts with representatives in this industry, it appeared the technology was available to manufacture sunlight-stable plastic. Most problems occurred with companies or employees new to the industry, poor mixing of ingredients prior to making stretch wrap plastic, or problems with the manufacturing equipment. The frequency of failures has declined over the years but several producers no longer make round bale silage because of their bad experience with plastic. If you notice sunlight degradation of stretch wrap plastic, it is suggested to feed this forage before it rots or rewrap the bales. Many problems can be avoided by testing new sources of stretch wrap on a few bales for one or more 
years before risking a considerable portion of your harvested forage.

Other problems with stretch wrap plastics have been air entry and spoilage without visible sunlight breakdown or visible holes. This problem has not been frequent and was usually traced to too few layers of stretch wrap, inappropriate stretching of the film (50 to $60 \%$ usually suggested), or reprocessed resins used in manufacturing of stretch wrap. Six layers of stretch wrap are recommended to reduce holes and keep the air out. Although four layers have been used successfully, spoilage has been found in a few instances when no holes were present. These problems may have been caused by using reprocessed resin to make stretch wrap plastic. Stretch wrap plastic manufacturers that used this cost cutting approach usually have not continued to market stretch wrap plastic.

Wrapping machine. The most common system in Florida is wrapping individual bales with stretch wrap. Although most of the older bale wrappers applied 20-inch-wide stretch wrap, most of the newer bale wrappers apply 20- and 30-inch-wide stretch wrap and 30-inch is used widely by producers for cost and time reasons. The pretensioner must evenly stretch the plastic at the specified amount; usually 50 to $60 \%$. Occasionally pretensioners will under- or overstretch plastic wrapping machines tilting their wrapping table for the bale to roll off the machine after wrapping. An uneven soil surface, rocks, stubble, etc. can puncture the stretch wrap or cause excessive stretching in a small area, which can lead to a hole after a few months of weathering. A table attachment on the wrapper that lowers the bale to the ground and decreases the distance a bale will roll is an option that can reduce plastic damage and reduce problems under some conditions.

In-line wrapping machines that wrap bales with stretch wrap in a long line were developed in the 90s. Round bales are loaded on this machine end to end, and wrapped with stretch wrap continuously. The wrapped bales move over rollers that gradually lower them to the ground as the machine moves ahead. In-line wrappers are less likely to damage stretch wrap after wrapping (they don't move wrapped bales or drop them to the ground) and they use about half as much stretch wrap for each bale as machines that wrap bales individually. Although in-line wrappers cost a bit more initially, the savings in plastic and labor may offset this in many situations.

Time of wrapping. How long can I wait from baling to wrapping bales? This has been a common question. Producers have observed that wet bales will heat if allowed to sit a few hours before wrapping. Air exposure and high moisture allows plant respiration and fungus (mold) growth, producing heat that is not dissipated once the wet forage is in a bale. Both plant respiration and fungus growth use water-soluble sugars that are the primary substrates for producing organic acids that lower the $\mathrm{pH}$ and ensile the forage. With this reasoning it seems obvious that wrapping soon after baling is recommended. However, forage producers know that labor is limited, equipment breaks down, and rains and lightning are common during the summer. A study evaluating the effects of delaying wrapping up to 48 hours was conducted over 2 years to help answer this question (Garces-Yepez et al., 1992). Bale temperatures reached over $150^{\circ} \mathrm{F}$ when wrapping was delayed 48 to 52 hours (Table 3). Bale temperatures declined and within 1 week after wrapping temperatures were below $140^{\circ} \mathrm{F}$ which is considered critical to avoid lowering protein digestibility caused by the high temperatures. Low acid detergent fiber nitrogen (ADFN) concentrations and similar concentrations across all time delays indicate higher temperatures did not increase ADFN which is indirectly related to reduced protein digestibility. Acid detergent fiber nitrogen concentrations averaged $8 \%$ and $6 \%$ of total nitrogen in the two trials. Differences in dry matter recovery percentages, in vitro digestibilities, and $\mathrm{pH}$ values for delaying wrapping up to 48 hours were not found in this trial. A visual evaluation of molding on the bales did not show differences either. This trial did not evaluate animal preferences, intakes, or performance, but large differences in forage preservation due to delaying wrapping up to 48 hours were not found. However, it is recommended to wrap bales the same day.

Storage issues: holes in the plastic resulting in molding and rotting of the forage have been the biggest problem with round bale silage. Animals 
and birds can and sometimes do make holes in the plastic. Problems with cattle, deer, hogs, raccoons, ground hogs, cats, rats, mice, and various birds have been reported. Choosing a storage area where prolems with these animals are less likely is the most workable solution. Tree limbs, hail, and soldier fly larva can also cause holes. Ants may not make the hole but have been observed to enter the bales and increase spoilage. Weekly monitoring of plastic for holes and patching with tape designed for this purpose is highly recommended. Bales with holes should be fed soon after holes are made (even if patched) or rewrapped if feeding time is a few months away. Bales damaged during wrapping should be rewrapped or separated so they can be fed first (patched areas tend to fail before undamaged plastic). Selecting bales with damaged plastic to feed first can help reduce losses.

Stacking bales has been tried but it is not recommended for most situations. Bales containing forage baled when too wet often shrink and these change in shape after a few months of storage. Piling these bales results in additional distortion in shape causing air leakage and bales falling off the pile. If storage space is limited and piling is necessary, consider stacking on end. Moving the wrapped bales with equipment that does not damage the plastic is essential.

Feeding issues. Round bale silage can be handled and fed much like hay. Plastic is usually removed and left in the storage area. Using a round bale feeder or unwrapping bales helps to reduce trampling and waste. Bales may start to heat after 2 to 4 days in the open air, but this heating is usually not as much of a problem as with chopped silage. Presumably, the dense bale slows the air entry that causes the heating. Offering round bale silage that will be consumed in 4 days or less has worked well. Molding and rotting can occur from holes in plastic and some of this forage will not be eaten. Molded forage that is consumed has not caused problems in most situations. White, pink, gray, and blue mold have been observed, but problems with cattle deaths or noticeable reductions in performance have not been reported. Horse deaths from botulism have been reported when round bale silage was fed. This was associated with dead animals (rats, mice, etc.) trapped during baling.

Plastic and wrapper costs. Round bale silage can be cost effective in some situations. Typical costs of equipment depreciation and plastic are itemized for the individual bale and in-line wrapping systems at different annual uses (Table 4).

These are extra costs above those for making hay. Feedback from producers with automated wrappers (wrappers with power supplies and automatic start and stop) that already haul their hay to storage areas indicated labor required to fluff hay prior to raking was similar to labor required to wrap silage bales. Costs associated with extra labor to wrap forage need to be added in some situations. Part of added costs for round bale silage will be offset by reduced field and storage losses compared to hay stored outside. Added costs range from $\$ 3.50$ to $\$ 8.50 /$ bale or $\$ 11$ to $\$ 27 /$ ton of dry forage.

\section{Forage Management Is Important}

Harvesting hay or round bale silage preserves the forage for feeding at a later time. Neither system improves the quality of harvested forage, therefore harvesting high quality forage is essential. Ensiling a forage requires an anaerobic environment (no oxygen) that allows fermentation of sugars to organic acids. Organic acids such as lactic acid lower the $\mathrm{pH}$ and this inhibits bacteria growth and fermentation. If fermentable sugars are gone before the $\mathrm{pH}$ is low enough, clostridia bacteria can grow breaking down lactic acid and protein to undesirable end products. Bermudagrass is difficult to ensile because of low sugar concentration (usually less than $4 \%$ fermentable sugars; Bates et al., 1989a), high buffering capacity (more lactic acid needed to lower $\mathrm{pH}$ ), and fermentation of some substrates (malic and oxaloacetic acids) to weak acids (acetic) that buffer near $\mathrm{pH} 5$. Wilting forage to $35 \%$ or higher dry matter is a strategy used to preserve forages like bermudagrass that are difficult to ensile. Higher dry matter inhibits the growth of the clostridia bacteria.

Wilting. Bermudagrass cut at 4 to 6 weeks regrowth is typically 18 to $28 \%$ dry matter at cutting. Wilting bermudagrass for 2 to 4 hours during good summer drying conditions increased dry matter 20 
percentage units to $46 \%$ dry matter, reduced bale weights over 100 pounds, and increased dry matter in each bale over 200 pounds (Table 5). Wilting forage 2 to 4 hours resulted $19 \%$ higher dry matter intake and .4 pounds per day higher gains in growing cattle. Bermudagrass wilted and stored as round bale silage had bale dry matter weight and cattle gains similar to those associated with forage harvested as hay, but storage and feeding losses were 4 to 6 percentage units better for hay. Wilting compared to direct cut round bale silage also reduces number of bales and storage costs by over $35 \%$.

Most perennial forages (bermudagrass, stargrass, limpograss, perennial peanut) should benefit from wilting prior to baling. Annual forages such as millet and sudan grass are very high in moisture when cut and wilting to increase dry matter is essential for good quality silage.

Additives. Microbial inoculants, enzymes, sugars, ammonia, and other additives can be added to enhance fermentation and preservation of silage. Limited research has been conducted with these additives on round bale silage. Microbial inoculants have been shown to increase the rate of fermentation and result in a lower final $\mathrm{pH}$ with chopped silage and similar results have been found with round bale silage (Bates et al., 1989a). Trials evaluating microbial inoculants that provide fast-growing, lactic-acid-producing bacteria often show advantages in silage fermentation but trials showing advantages in dry matter recovery and cattle performance are limited. Research evaluating effects of microbial inoculation of bermudagrass round bale silage produced mixed results. Growing cattle fed microbial inoculated (lactic acid bacteria) bermudagrass round bale silage had .16 pounds per day higher gains (.08 versus .24 pounds per day) than those fed uninoculated direct cut silage (70-75\% moisture), but microbial inoculation did not improve performance (.50 versus .44 pounds per day) in wilted (50-60\% moisture) bermudagrass round bale silage. This research showed higher intakes and performance for inoculated direct cut bermudagrass silage but gains of these cattle were still below gains of cattle fed wilted silage indicating wilting was more important than inoculation. An evaluation of several experiments suggests that microbial inoculants often give improvements when ensiling conditions are marginal.

Ammonia is a mold inhibitor and has been shown to reduce visible molds on the outside of bales (Bates et al., 1989b). Unfortunately, ammoniation ( $1 \%$ of dry matter) has been associated with an undesirable fermentation in direct cut bermudagrass round bale silage characterized by more acetic acid and a higher $\mathrm{pH}$. Enzyme additives to bermudagrass silage have shown promising results by increasing the fermentable substrate (Bates et al., 1989b), however the specific enzymes and quantities (activities) needed for the optimal effect has not been determined.

\section{Summary}

The round bale storing system allows harvesting warm season grasses every 4 to 5 weeks when the quality is good. This will reduce or eliminate the need for supplements when feeding the forage to beef cattle. Plan to cut warm season grass by the calendar, make hay when the weather allows, and make round bale silage when the weather will not allow drying for hay. Quality of round bale silage is dependent on excluding air from the ensiled forage. Holes in the plastic resulting in molding and rotting of the forage have been the biggest problem with round bale silage. Wilting warm season grasses to increase dry matter 40 to $50 \%$ before baling reduces number of bales and storage costs, decreases storage losses, and improves cattle performance.

\section{Literature Cited}

Bates, D.B., W.E. Kunkle, C.G. Chambliss, and R.P. Cromwell. 1989a. Effect of dry matter and additives on bermudagrass and rhizoma peanut round bale silage. J. Prod. Agric. 2:91-96.

Bates, D.B., W.E. Kunkle, T.E. Dawson, A. Berthe, S.C. Denham, C.G. Chambliss, R. C. Cromwell, J.G. Wasdin, and D.L. Wakeman. 1989b. Round bale silage - A forage harvesting alternative. Proc. $38^{\text {th }}$ Annual Beef Cattle Shortcourse, pp 45-55, Univ. of Florida.

Berthe, A., W.E. Kunkle, and D.B. Bates. 1991. Effects of harvesting system and wilting on bermudagrass intake and liveweight change of growing heifers. J. Anim. Sci. 69:283 (Suppl. 1). 
Brown, W.F. and R.S. Kalmbacher. 1998.

Nutritional value of native range and improved forages: A perspective from central and south Florida. Proc. $47^{\text {th }}$ Annual Beef Cattle Shortcourse, pp 79-87, Univ. of Florida, Gainesville.

Cromwell, R.P., W.E. Kunkle, and C.G. Chambliss. 1994a. Equipment for preserving forage as round-bale silage. Cooperative Extension Service, Circular 1071, 7 pp, Univ. of Florida, Gainesville.

Cromwell, R.P., W.E. Kunkle, G.D. Sadler, and C.G. Chambliss. 1994b. The plastic wrapper is the key to making high quality round bale silage.

Cooperative Extension Service, Circular 1072, 6 pp, Univ. of Florida, Gainesville.

Yepez, P.G., W.E. Kunkle, and D.B. Bates. 1992. Effect of delaying storage on the dry matter recovery and quality of bermudagrass ensiled in round bales wrapped with plastic. J. Anim. Sci. 70:191 (Suppl. 1). 
Table 1. Effects of grass and maturity (age in weeks) on forage quality. ${ }^{a}$

\begin{tabular}{lcccccccccc}
\hline \multirow{2}{*}{ Grass } & \multicolumn{3}{c}{ TDN $^{\mathrm{b}}$} & \multicolumn{3}{c}{} & \multicolumn{3}{c}{ Voluntary intake $^{\mathrm{C}}$} & \multicolumn{3}{c}{ Quality index $^{\mathrm{d}}$} \\
\cline { 2 - 10 } & 4 & 6 & 8 & 4 & 6 & 8 & 4 & 6 & 8 \\
\hline Bahia & 56 & 55 & 54 & 2.3 & 2.1 & 1.7 & 1.2 & 1.1 & .9 \\
Bermuda & 57 & 52 & 44 & 2.3 & 2.2 & 1.8 & 1.3 & 1.1 & .8 \\
Star & 60 & 53 & 49 & 2.4 & 2.5 & 2.1 & 1.4 & 1.3 & 1.0 \\
Digit & 60 & 58 & 57 & 2.5 & 2.7 & 2.2 & 1.5 & 1.5 & 1.2 \\
Limpo & 63 & 63 & 56 & 2.5 & 2.3 & 2.2 & 1.5 & 1.4 & 1.2 \\
\hline
\end{tabular}

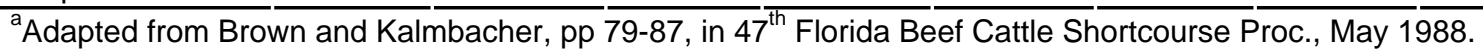

${ }^{\mathrm{b}}$ Total Digestible Nutrients, percentage of dry matter.

${ }^{\mathrm{C}}$ Intake of dry matter expressed as percent of body weight.

${ }^{d}$ Voluntary TDN intake relative to maintanence requirement: $1.0=$ maintanence.

Table 2. Quality of coastal bermudagrass hay harvested at different maturities and seasons. ${ }^{a}$

\begin{tabular}{|c|c|c|c|c|c|c|}
\hline \multirow[b]{2}{*}{ Item } & \multirow{2}{*}{$\begin{array}{l}\text { Weeks of } \\
\text { regrowth }\end{array}$} & \multicolumn{5}{|c|}{ Harvest date } \\
\hline & & $06 / 14$ & $07 / 12$ & 08/09 & $09 / 06$ & $10 / 04$ \\
\hline \multirow{3}{*}{ TDN, \% DM ${ }^{b}$} & 4 & 55 & 57 & 52 & 53 & 46 \\
\hline & 6 & 52 & 51 & 47 & 49 & 48 \\
\hline & 8 & 52 & 51 & 46 & 47 & 44 \\
\hline \multirow{3}{*}{$\mathrm{QI}^{\mathrm{c}}$} & 4 & 1.4 & 1.4 & 1.3 & 1.3 & 1.1 \\
\hline & 6 & 1.3 & 1.4 & 1.0 & 1.2 & 1.2 \\
\hline & 8 & 1.3 & 1.1 & .9 & 1.1 & .8 \\
\hline \multirow{3}{*}{$A D G, I b^{d}$} & 4 & .57 & .78 & .72 & .63 & .28 \\
\hline & 6 & .34 & .48 & -.04 & .42 & .22 \\
\hline & 8 & .16 & .07 & -.39 & .07 & -.39 \\
\hline
\end{tabular}

${ }^{a}$ Adapted from Nelson, et al., 1980, Louisiana Agr. Exp. Sta. Bul. 730.

${ }^{\mathrm{b}}$ Total Digestible Nutrients, percentage of dry matter.

${ }^{c}$ Voluntary TDN intake relative to maintenance requirement: $1.0=$ maintenance.

${ }^{d}$ Daily gains, in pounds; feeding trial conducted with steers from December through February for all hays. 
Table 3. Effects of delaying time from baling to wrapping on bermudagrass round bale silage. ${ }^{a}$

\begin{tabular}{|c|c|c|c|c|c|}
\hline & \multicolumn{5}{|c|}{ Time from baling to wrapping, $\mathrm{hr}$} \\
\hline & $1-4$ & $19-22$ & $27-31$ & $48-52$ & S.E. \\
\hline \multicolumn{6}{|l|}{ Year $1989^{b}$} \\
\hline - Dry matter recovery, \% & 99.5 & 96.0 & 101.6 & 100.8 & 3.0 \\
\hline - ADF-N ${ }^{c}, \% D M$ & .17 & .15 & .13 & .14 & .02 \\
\hline - IVOMD, \% ${ }^{\mathrm{D}}$ & 50.0 & 50.3 & 52.4 & 50.7 & .92 \\
\hline$\cdot \mathrm{pH}$ & 5.81 & 6.02 & 5.99 & 5.95 & .07 \\
\hline \multicolumn{6}{|l|}{ - Temperature, (days 9-14) } \\
\hline - Peak, $F^{\circ}$ & 88 & 93 & 95 & 104 & 1.4 \\
\hline - Average, $\mathrm{F}^{\circ}$ & 83 & 86 & 87 & 91 & 1.1 \\
\hline \multicolumn{6}{|l|}{ Year $1990^{\circ}$} \\
\hline - Dry matter recovery, \% & 96.5 & 97.1 & 98.5 & 98.9 & 2.0 \\
\hline - ADF-N ${ }^{c}, \% D M$ & .08 & .08 & .08 & .10 & .01 \\
\hline - IVOMD, \% ${ }^{\mathrm{D}}$ & 39.0 & 42.1 & 42.4 & 41.7 & .93 \\
\hline$\cdot \mathrm{pH}$ & 5.40 & 5.47 & 5.46 & 5.77 & .11 \\
\hline \multicolumn{6}{|l|}{ - Temperature, (days 3-8) } \\
\hline - Peak, $F^{\circ}$ & 118 & 133 & 136 & 150 & 1.8 \\
\hline - Average, $\mathrm{F}^{\circ}$ & 112 & 121 & 123 & 136 & .7 \\
\hline
\end{tabular}

${ }^{\mathrm{a} G a r c e s-Y e p e z, ~ e t ~ a l ., ~} 1992$.

${ }^{b}$ Bales made on October 31, 1989; bale weight averaged 1,035 lb; $37.3 \%$ dry matter.

${ }^{\mathrm{C}}$ Acid detergent fiber nitrogen as a percent of dry matter.

dIn-vitro organic matter digestibility.

${ }^{e}$ Bales made on September 6, 1990; bale weight averaged 1,275 lb; $38.0 \%$ dry matter.

Table 4. Depreciation and plastic costs for two round bale silage wrapping systems. ${ }^{a}$

\begin{tabular}{|c|c|c|c|c|c|c|}
\hline \multirow[b]{2}{*}{ Bales/year ${ }^{b}$} & \multicolumn{3}{|c|}{ Individually wrapped bales } & \multicolumn{3}{|c|}{ In-line wrapped bales } \\
\hline & 500 & 1,000 & 2,000 & 500 & 1,000 & 2,000 \\
\hline Hay, tons ${ }^{c}$ & 180 & 360 & 720 & 180 & 360 & 720 \\
\hline Wrapper depreciation, $\$ /$ bale ${ }^{\text {de }}$ & 5.00 & 2.50 & 1.25 & 6.00 & 3.00 & 1.50 \\
\hline Stretch wrap plastic, $\$ /$ bale & 3.50 & 3.50 & 3.50 & 2.00 & 2.00 & 2.00 \\
\hline Total cost, $\$ /$ bale & 8.50 & 6.00 & 4.75 & 8.00 & 5.00 & 3.50 \\
\hline Total cost, $\$ /$ ton dry forage & 27.00 & 19.00 & 15.10 & 25.40 & 15.90 & 11.10 \\
\hline
\end{tabular}

\footnotetext{
${ }^{\mathrm{a}}$ Added costs above hay harvest, additional labor required in some situations.

${ }^{\mathrm{b}}$ Bales 4 feet wide by 5 feet high, $1,400 \mathrm{lb}, 45 \%$ dry matter, $630 \mathrm{lb}$ dry matter/bale.

${ }^{\mathrm{c}}$ Tons of hay with equivalent dry forage.

${ }^{d}$ Individual bale wrapper $\$ 12,500$ cost; depreciated over 5 years, $\$ 2,500 /$ year.

${ }^{\mathrm{e}}$ In-line bale wrapper $\$ 15,000$ cost; depreciated over 5 years, $\$ 3,000 /$ year.
} 
Table 5. Effects of wilting bermudagrass round bale silage on forage preservation and performance of growing cattle. ${ }^{\text {ab }}$

\begin{tabular}{lcccc}
\hline & \multicolumn{3}{c}{ Wilting time, hours } & Hay \\
\cline { 2 - 4 } & None & $1-2$ & $2-4$ & 87.4 \\
Forage dry matter, \% & 26.8 & 36.2 & 45.9 & 710 \\
Wet bale weight, lb & 1,450 & 1,425 & 1,340 & 620 \\
Dry bale weight, lb & 390 & 515 & 620 & 3.0 \\
Storage losses, \% & 12.5 & 11.5 & 8.8 & 12.5 \\
Feeding losses, \% & 10.1 & 12.7 & 16.8 & 9.82 \\
Dry matter intake, lb & 8.58 & 9.55 & 10.20 & +.28 \\
Daily gain, lb & -.15 & +.02 & +.26 & \\
\hline
\end{tabular}

${ }^{a}$ Berthe et al., 1991; Research conducted over two years, bermudagrass cut after 5 to 6 weeks regrowth in Year 1 and 6 to 7 weeks regrowth in Year 2.

${ }^{\mathrm{b}}$ Bales were 4 feet wide and 4.5 feet high made with New Holland 848 baler. High moisture forage wrapped with 4 layers of "stretch wrap" plastic.

${ }^{\circ}$ Cattle weighed $550 \mathrm{lb}$ at start of trial in Year 1; cattle weighed $520 \mathrm{lb}$ at start of trial in Year 2. 